\title{
Family resilience and parenting stress in poor families
}

\author{
Resiliência familiar e estresse parental em famílias pobres
}

\author{
Ísis de Cássia Palheta da SILVA ${ }^{1}$ [D 0000-0002-6350-8464 \\ Katiane da Costa CUNHA ${ }^{2}$ (iD) 0000-0001-5361-5090 \\ Edson Marcos Leal Soares RAMOS ${ }^{3}$ iD 0000-0001-5425-8531 \\ Fernando Augusto Ramos PONTES ${ }^{2}$ ID 0000-0001-9569-943X \\ Simone Souza da Costa SILVA ${ }^{2}$ (D) 0000-0003-0795-2998
}

\begin{abstract}
This quantitative and cross-sectional study aimed to describe and associate the levels of resilience, parenting stress and multidimensional poverty of poor families living in the city of Belém (PA). The probabilistic sample consisted of 429 caregivers, interviewed in Social Assistance Reference Centers, where the application of instruments to access socio-demographic information, family resilience, parenting stress and poverty was carried out, in order to investigate protection and risk processes for development. The sample consisted of women (97\%) between 20 and 39 years (69\%). This study showed associations between low resilience, high parenting stress and higher level of poverty. None of the families had high resilience scores. These results point to aspects regulating family dynamics as crucial in the healthy development of these families in relation to risk exposure.
\end{abstract}

Keywords: Family relations; Poverty; Stress, psychological.

\section{Resumo}

Este estudo quantitativo e transversal objetivou descrever e associar os níveis de resiliência, estresse parental e pobreza multidimensional de famílias pobres residentes em Belém, no Pará. A amostra probabilística foi constituída de 429 cuidadores entrevistados em Centros de Referência em Assistência Social, onde foram aplicados instrumentos para acessar

$\mathbf{v} \mathbf{\nabla} \boldsymbol{\nabla}$

1 Universidade Federal do Pará, Núcleo de Teoria e Pesquisa do Comportamento. Belém, PA, Brasil.

2 Universidade Federal do Pará, Núcleo de Teoria e Pesquisa do Comportamento, Programa de Pós-Graduação em Teoria e Pesquisa do Comportamento. Av. Perimetral, 2224, Guamá, 66075-110, Belém, PA, Brasil. Correspondence to: S.S.C SILVA. E-mail: <symon.ufpa@gmail.com>.

3 Universidade Federal do Pará, Instituto de Ciências Exatas e Naturais, Programa de Pós-Graduação em Segurança Pública. Belém, PA, Brasil.

Support: Conselho Nacional de Desenvolvimento Científico e Tecnológico (Protocol no 3077182013-1).

How to cite this article

Silva, I. C. P., Cunha, K. C., Ramos, E. M. L. S., Pontes, F. A. R., \& Silva, S. S. C. (2021). Family resilience and parenting stress in poor families. Estudos de Psicologia (Campinas), 38, e190116. https://doi.org/10.1590/1982-0275202138e190116 
informações sociodemográficas, de resiliência familiar e de estresse parental e pobreza, a fim de investigar processos de proteção e risco para o desenvolvimento. A amostra se compôs de mulheres (97\%) entre 20 e 39 anos (69\%). Foram observadas associações entre resiliência baixa, alto estresse parental e maior nível de pobreza e nenhuma das famílias obteve alto nivel de resiliência familiar. Esses resultados apontam para aspectos reguladores da dinâmica familiar como cruciais no desenvolvimento saudável dessas familias frente à exposição a riscos.

Palavras-chave: Relações familiares; Pobreza; Estresse psicológico.

Resilience studies in Brazil have gained strength since the 1990s and reveal, above all, the attempt to understand risk and protection processes for the development of children and adolescents. These studies reveal conceptual, theoretical, and methodological controversies and how researchers seek to decipher this phenomenon from different research possibilities (Rozemberg, Avanci, Schenker, \& Pires, 2014).

Initially, the predominant understanding about resilience was that it was a personality trait, later the notion that it derives from the association of complex processes that explain coping and overcoming crises and adversities was adopted (Oliveira, Nakano, \& Silva, 2019). In this perspective, this phenomenon can be understood according to its systemic qualities, described by psychosocial processes that favor the adaptation of an individual or group in the face of adversity (Yunes \& Szymanski, 2007).

Resilience, therefore, can be defined as the ability to resist and recover from life's challenges, based on dynamic processes that promote positive adaptation in the context of significant adversities (Walsh, 2015). In this context, the role of the family in the development of resilience is undeniably important, as it is characterized as the main source of reference and support for children and adolescents. The family group can be understood as a system made up of individuals organized in a microsystem that has its own rules and characteristics. This microsystem has functionalities that are under the influence of complex variables, such as social class and culture (Bronfenbrenner \& Morris, 2006).

Such components are relevant to understanding the functionality of families, as they can indicate elements of risk and protection for development, since risks and opportunities can occur in proximal and distal contexts (Henry, Hubbard, Spencer, \& Struckmeyer, 2018). According to this perspective, McCubbin and Patterson (1983) and Patterson (2002) consider that the ability of families to cope and adapt in the face of adversity is related to four fundamental aspects: (1) the characteristics of the individuals who make up the family system; (2) the internal resources of the family; (3) community resources available to the family; and (4) the family's perception of adversities. It is the dynamic relationship between these factors that will define the system's ability to restore balance, through the reduction of demands, the enhancement of capacities and/or the reframing of meanings referring to both the stressful event, the family unit and the world (Patterson, 2002).

In an attempt to systematize family functioning in the face of adversity, Walsh (2015) organized three domains that represent family processes under stressful situations: the belief system, organizational patterns and communication processes. The belief system allows the family to face their difficulties with optimism, connecting, for example, to the feeling of religiosity. The organizational patterns are related to flexibility, cohesion (support, collaboration, search for reconciliation) and social and economic resources. Communication processes are facilitators of interactions as they allow the exchange of information, the development of empathy and shared decision-making (Dell'Aglio, Koller, \& Yunes, 2011).

Family resilience can be understood as the family's ability to reduce the disturbing impact of one or more stressful situations through relational processes that allow the influence of demands while allowing individuals to find resources, as well as the possible expansion or creation of resources over time (Henry et al., 2018). In this perspective, elements of the mesosystem such as the social and affective support network 2 are also undeniably important, the interactions carried out in the community, the network of relationships, 
religion and other similar groups reflect the relational quality of family members and the possibility of maturity and psychological development (Walsh, 2015).

In general terms, the notion of resilience is, according to Sousa and Araujo (2015), strongly linked to the understanding of risk and protection factors. Risk factors operate by restricting the likelihood of overcoming shortcomings or increasing their effects. Their impact, however, is reduced by protective factors, which work by limiting damage and promoting emotional stability. Yet, according to Patterson (2002), resilience consists of a processual phenomenon, which occurs over time, presenting itself according to environmental, personal and or temporal circumstances (Anjos \& Astorga, 2016).

Conger and Conger (2002) demonstrated in a longitudinal study, that parents who are resilient to economic adversities also had less marital conflicts and better problem-solving skills, while having more resilient children during the transitions experienced over time. This investigation demonstrates the strong relational aspect in building resilient responses, suggesting that family resilience encompasses interactive processes that can strengthen the phenomenon of individual resilience. Thus, the family is understood as a functional unit that can increase the resilience and vulnerability of all its members (Patterson, 2002).

Based on the understanding of the fundamental role played by the family, developmental psychology researchers have turned to the study of families exposed to poverty situations that can be classified as risky, severe, intense, and constant (Hughes, Power, Liu, Sharp, \& Nicklas, 2015; Steele et al., 2016). The condition of poverty in which some families live has been associated with negative consequences for the development of children, adolescents, and adults. Main and Bradshaw (2016) consider that the well-being of children is severely affected by poverty or its elements. In a literature review, Maitoza (2019) pointed out, when investigating the effects of economic tension and unemployment on mental health, that these variables interfere in the marital relationship and in the quality of parental interactions.

When mentioning the parent-child relationship, the literature highlights how much this subsystem is mediated by parenting stress, which has a multidimensional genesis (Abidin, Austin, \& Flens, 2013). Parenting stress is a type of stress experienced by adults in their parenting activities, the result of interactions between the adult who is the parent or guardian (caregiver) and the vulnerable member, usually a child or an adolescent (Lima, Cardoso, \& Silva, 2016). Empirical evidence reveals that the experience of parenting can become more stressful when it is lived in conditions of poverty (Steele et al., 2016).

According to the Indian economist and philosopher Sen (2018), poverty is a multidimensional phenomenon. This means that the analysis of its constitution must take into account not only income, in a unidimensional view, but multiple aspects that make up people's vulnerability and influence their well-being and their potential to develop, such as social, cultural and political characteristics, focusing on the functionalities that can be obtained from the resources that a family has.

In Brazil, Barros, Carvalho, and Franco (2006) operationalized an instrument that aims to assess poverty in a multidimensional perspective, called the Family Poverty Index (FPI) using indicators that go beyond the income issue, such as education and basic sanitation. The work of Barros et al. (2006) allowed, in this research, to classify families according to their degree of poverty. The application of the FPI allowed Barros et al. (2006) to consider that $25 \%$ of Brazilian families are poor in a multidimensional perspective. The authors also exhibit the result that the situation of poverty is different for the most vulnerable groups. For example, it shows that the poverty indicator of members of families headed by women reached $28 \%$, a higher result than the national average.

In possession of the FPI, Silva, Cunha, Ramos, Pontes, and Silva (2019) associated the levels of multidimensional poverty and parenting stress, demonstrating the existence of relationships between poverty deprivation and family functioning. This was demonstrated, especially, in the access to knowledge, access to income and child development dimensions. 
According to data from the Instituto Brasileiro de Geografia e Estatística (2018), the state of Pará was among the most unequal states in Brazil. In 2019, according to the same research institute, the distribution of individuals without an occupation in the Metropolitan Region of Belém (PA) was higher for the 25 to 39 age group (36.8\%). In this group, it is also noted that $53.3 \%$ are women.

In this sense, the strong line of continuity between poverty and situations of social vulnerability of families is undeniable. Thus, investigations on the way of life of poor families, considering sociocultural differences and fundamental aspects of development, are paramount (Bem \& Wagner, 2006). In a multidimensional perspective, a family with deficits, especially in aspects such as knowledge and work, has a different poverty profile than another family with deficits in aspects such as housing and housing conditions (Barros et al., 2006).

It is evident, therefore, that the analysis of factors such as family resilience, parenting stress and multidimensional family poverty is approached from an integrative and systemic perspective. In this sense, the objective of this study is to analyze processes of family resilience, parenting stress and family poverty, from the description and association between the variables, in order to outline a quantitative picture on how they are organized in the experiences of poor families in the city of Belém (PA), Brazil.

\section{Method}

\section{Participants}

The research participants were 429 caregivers registered in the Brazilian federal government's Cadastro Único (CadÚnico, Unified Registry) system, a database that gathers information about families in situations of poverty and extreme poverty. Families are linked to the CadÚnico system through the Centro de Referência em Assistência Social (CRAS, Social Assistance Reference Centers) in their own neighborhoods or districts, in order to be able to receive federal social benefits, such as Bolsa Familia, a social welfare program.

In the construction of the eligibility criteria of the participants, it was established that families registered in the CadÚnico system would participate in the research, being requested to the Ministério do Desenvolvimento Social e Combate à Fome (Ministry of Social Development and Hunger Combat) the database of families inserted in the Cadúnico of the city of Belém (PA), until August, 2015. From the information that 154,779 individuals were registered, the sample calculation of families to be collected according to their neighborhood or district in the municipality was carried out. For that, the procedures of Simple Random Sampling and Stratified Random Sampling were used.

Participants were selected according to their neighborhood or district, in order to build the stratified probability sample for the neighborhoods or districts of the mainland area of Belém. In order to participate in the research, in addition to registering to the CadÚnico system, identified by the Social Identification Number, the caregiver should meet the criterion of having or being responsible for children between 5 and 18 years old, living in the locations surveyed. The children's age criterion was developed based on the assumptions of the instruments used in the research project to which this study is linked.

\section{Instruments}

Four instruments were used in this study: the Sociodemographic Inventory (SDI); the Family Resilience 4 Profile Questionnaire; the Family Poverty Index (FPI); and the Parenting Stress Index (PSI). The Sociodemographic 
Inventory was used in order to record the main family data, family composition, sociodemographic information, and economic characteristics of the participating families. It is an instrument built by the team of researchers from the Ecological Development Laboratory and traditionally used in research (Santos, Silva, \& Koller, 2017).

The Family Resilience Profile Questionnaire is a multidimensional instrument structured to assess how the family develops skills to adapt to crisis situations. It consists of five subscales: Family Changes, Family Coherence, Family Flexibility, Family Involvement and Family Social Support. The instrument used in this study was adapted from McCubbin and McCubbin (1993) by Peixoto and Martins (2012) for the Portuguese population.

The five subscales have a specific number of items according to the investigated family characteristics, following the Resilience, Stress, Adjustment and Family Adaptation Model (Patterson, 2002). The Family Changes subscale assesses events and changes that have occurred that may expose the family to greater vulnerability through a list of experiences, such as changes in employment, the onset of illnesses, separation, divorce or death. The Family Involvement subscale assesses the relationship and closeness between family members and their implications for overall well-being. In the Social Support subscale, six items: 7, 9, 10, 13,14 and 17 were inverted so that a higher score corresponded to a greater support, according to Peixoto and Martins (2012). The latter is intended to identify the extent to which the family is integrated into the community, sees it as a resource and how the family feels the emotional support, as well as the support received from friends and family members. The Family Coherence subscale focuses on the family's abilities to deal with stressful events and changes. The Family Flexibility subscale contains items related to the participation of elements in family decisions (including children), how to deal with problems and how they share responsibilities.

The determination of the resilience profile of the family is determined by the final scores of each scale, allowing to determine a low, moderately or highly resilient profile for each of the studied variables. The adaptation of the instrument by Peixoto and Martins (2012) for a convenience sample of Portuguese caregivers reveals good consistency regarding the Family Flexibility $(\alpha=0.60)$, Family Involvement $(\alpha=0.68)$ and Social Support ( $\alpha=0.78$ ) subscales. The Family Changes and Family Coherence subscales had low consistency. The authors suggest new studies that may clarify the validity of the entire instrument.

The FPI is an instrument aligned with the concept of multidimensional poverty. Developed by Barros et al. (2006), it includes a total of six dimensions, 26 components and 48 indicators and was used in order to measure the degree of multidimensional poverty for each family. The indicators are structured as questions, to which families could answer as "yes" or "no". The binary organization of responses allows to represent satisfied and unsatisfied needs, which result in an increase or decrease in the poverty indicator.

The weighting of the index consists of a variation from 0 (for non-poor families) to 100 (for absolutely poor families). This variation in the degree of poverty defined by the FPI analysis model allowed the families in this study to be classified as "poorer" and "less poor". The six dimensions of poverty assessed are: vulnerability; access to knowledge; access to work; scarcity of resources; child development; and housing shortcomings.

The Parenting Stress Index Short Form (Abidin, 1990) was applied in order to assess the level of parenting stress perceived by caregivers. This instrument consists of a tool that assesses the degree of stress that caregivers are experiencing. It has been used in Brazil in theses and dissertations, which focus on parenting in different contexts (Lima, Cardoso, \& Silva, 2016).

It consists of a scale of 36 items divided into three subscales of 12 items: the Parental Suffering subscale assesses the perceptions about the feelings experienced by parent in their parenting roles; the Dysfunctional Father/Child Interaction subscale, to assess the parents' perceptions of their children, and which of these are compatible or not with their expectations, as well as evaluating the perceptions about the mother/child 
interactions that reinforce or not their parenting roles; and the Difficult Child subscale, which specifies some basic characteristics of the child that facilitate or not the management of their behaviors. The sum of the points assigned to each item defines the total score, which can vary from 36 to 180 . This sum is performed considering the subscales, through the values displayed on the Likert scale of the instrument (Likert scale ranging from 1 = strongly disagree, $2=$ disagree, $3=$ not sure, $4=$ agree and $5=$ totally agree) (Pereira, Vieira, Toso, Carvalho, \& Bugs, 2016).

The score obtained in the total analysis of the PSI items and in their dimensions allows to classify stress levels as low, normal, or high. The research by Reitman, Currier, and Stickle (2002) in a population of low-income mothers had a Cronbach's alpha of 0.95 for the total stress coefficient that demonstrated a high internal consistency of the measures used to describe parenting stress.

\section{Procedures}

Caregivers present at the CRAS in order to be re-enrolled in the Bolsa Familia Program or in other type of program were approached individually while waiting in line. The CRAS is a functional unit of the Sistema Único de Assistência Social (Unified Social Support System) that works in areas of social vulnerability with families and individuals in their communities (Nascimento \& Curado, 2017). The participants received the Informed Consent Term and, after signing it, the researcher applied the interview using the instruments. All interviews were conducted individually and happened only once with each participant. After the application of the instruments, data was registered in the $\mathrm{IBM}^{\circledR}{ }^{\circledR}$ SSSS ${ }^{\circledR}$ Statistical package software (version 23.0).

\section{Data analysis}

The resilience variable was the starting point of the data analysis performed. Considering that the determination of the family's resilience profile is carried out through the final scores of each scale, families can be classified as low, moderately, or highly resilient. Based on the classification of resilience levels, the database was separated into groups, in which the proportion of levels of parenting stress and family poverty was identified.

Initially, to classify families according to the family resilience profile, the table provided by Peixoto and Martins (2012), generated from the adaptation of the instrument to the Portuguese population, was used. The total scale ranges from 0 to 68 points, divided into subscales. The classification of participants in each subscale was performed based on the Sample Quartiles Theory (Bussab \& Morettin, 2013).

After a descriptive analysis of each variable, they were listed in multivariate analysis. For this, some appropriate statistical tests were applied to the data structure. The Correspondence Analysis technique was used for this purpose. Thus, the study was developed in stages. According to Fávero, Belfiore, Silva, and Chan (2009), correspondence analysis is an exploratory statistical technique used to verify associations or similarities between qualitative variables or categorized continuous variables. In the tests performed in this study, $\alpha=5 \%(p \leq 0.05)$, to reject the null hypothesis. Correspondence analysis was performed with the aid of the Statistica software (version 6.0).

\section{Ethical considerations}

The research is part of a macroproject entitled "Poverty and Development Ecology", approved by the

6 Scientific Research Ethics Committee, from the Faculty of Tropical Medicine of the University of Pará, under 
the opinion number 865.235. In addition, the present study was authorized by the administrators of every CRAS responsible for each neighborhood or district. The research followed the ethical precepts of Resolution $n^{\circ} 466$ of 2012, which guides scientific research with human beings to meet "pertinent ethical and scientific standards" and Resolution 510 of 2016, which provides for the applicable rules to research in Human and Social Sciences whose methodology uses identifiable data.

\section{Results}

The results were organized into: (1) sociodemographic characteristics; (2) descriptive data on family resilience, parenting stress, and family poverty; and (3) multivariate analysis of family resilience, parenting stress and family poverty.

\section{Sociodemographic characteristics}

In this section, the main sociodemographic characteristics of the 429 participants obtained from the SDI will be presented. It is observed that an expressive percentage of $96.4 \%$ of caregivers are women (mothers and grandmothers), and $2.6 \%$ are men. The age group between 20 and 39 years old was the age group with the highest proportion among caregivers (68.5\%), followed by the group between 40 and 49 years old (22.0\%).

Regarding education, the result was that $50.3 \%$ of these caregivers completed high school, $25.2 \%$ completed elementary school and $21.2 \%$ did not complete elementary school. Regarding access to work, $54 \%$ of caregivers reported working away from home, mainly in the informal market (66.4\%). In addition, it is observed that only $5.4 \%$ of families have a working adult whose income bracket is above two minimum wages.

\section{Descriptive data on family resilience, parenting stress and family poverty}

Table 1 presents the data collected with the instruments of family resilience, which classified families into low, moderately, and highly resilient; parenting stress, with low, normal, and high stress ratings; and family poverty, classified as poorer and less poor. Descriptive data are presented in relation to the results of the resilience groups, but the absolute data that represented most individuals in the resilience, stress and poverty groups are also presented.

In the studied population, the data revealed a predominance of individuals with a low resilient profile, corresponding to $80.2 \%$ (344) of the study sample. Table 1 shows the frequency and percentage of participants classified as "low" and "moderately" resilient, in relation to the poverty and stress variables.

Table 1

Descriptive data on family resilience, parenting stress, and family poverty $(n=429)$. Belém (PA), Brazil, 2016

\begin{tabular}{|c|c|c|c|c|c|c|c|c|}
\hline \multirow{3}{*}{ Family resilience } & \multicolumn{4}{|c|}{ Parenting stress } & \multicolumn{4}{|c|}{ Family poverty } \\
\hline & \multicolumn{2}{|c|}{ Low } & \multicolumn{2}{|c|}{ High } & \multicolumn{2}{|c|}{ Poorer } & \multicolumn{2}{|c|}{ Less poor } \\
\hline & $f$ & $\%$ & $f$ & $\%$ & $f$ & $\%$ & $f$ & $\%$ \\
\hline Low $(n=344)$ & 196 & 45.7 & 148 & 34.5 & 164 & 38.2 & 180 & 42.0 \\
\hline Moderate $(n=85)$ & 61 & 14.2 & 24 & 5.6 & 37 & 8.6 & 48 & 11.2 \\
\hline
\end{tabular}

Note: $f$ : Frequency. 
Analysis of family resilience data revealed that, in addition to the $80.2 \%$ (344) low resilient caregivers, $19.8 \%$ (85) were classified as moderately resilient and $0.0 \%$ of the participants had high resilience scores. It is important to stress that none of the individuals were highly resilient, according to the instrument's parameters, that is, none of the families scored enough points to reach this classification.

\section{Multivariate analysis of family resilience, parenting stress and family poverty}

Table 2 shows the statistics resulting from the application of the Correspondence Analysis technique for the family resilience, parenting stress and family poverty variables. Table 2 shows the Family Resilience variable and is related to the Parenting Stress and Family Poverty variables through the Correspondence Analysis technique. There is a strongly significant association between low resilience and high parenting stress $(99.34 \%)$, in addition to a moderate association between families with low resilience and greater poverty levels (51.84\%). On the other hand, families classified as having moderate resilience were strongly associated with low parenting stress (100.00\%). In relation to poverty, this resilience group was associated with the poorer families with a moderately significant probability $(51.84 \%)$ and with the less poor families, with a strong probability (81.62\%).

Table 2

Results of the correspondence analysis for family resilience, parenting stress, and family poverty $(n=429)$. Belém (PA), Brazil, 2016

\begin{tabular}{|c|c|c|c|c|c|c|c|c|}
\hline \multirow{3}{*}{ Family resilience } & \multicolumn{4}{|c|}{ Parenting stress } & \multicolumn{4}{|c|}{ Family poverty } \\
\hline & \multicolumn{2}{|r|}{ Low } & \multicolumn{2}{|r|}{ High } & \multicolumn{2}{|r|}{ Poorer } & \multicolumn{2}{|r|}{ Less poor } \\
\hline & $R$ & Confidence level & $R$ & Confidence level & $R$ & Confidence level & $R$ & Confidence level \\
\hline $\begin{array}{l}\text { Low } \\
\text { Moderate }\end{array}$ & $\begin{array}{r}-2.22 \\
4.47\end{array}$ & $\begin{array}{c}(0.00) \\
(100.00)^{*}\end{array}$ & $\begin{array}{r}2.71 \\
-5.46\end{array}$ & $\begin{array}{c}(99.34)^{*} \\
(0.00)\end{array}$ & $\begin{array}{l}0.70 \\
0.70\end{array}$ & $\begin{array}{l}(51.84)^{* *} \\
(51.84)^{* *}\end{array}$ & $\begin{array}{r}-0.66 \\
1.33\end{array}$ & $\begin{array}{c}(0.00) \\
(81.62)^{*}\end{array}$ \\
\hline
\end{tabular}

Note: "Strongly significant probabilities, as $\gamma \times 100 \geq 70 \%$; ${ }^{* *}$ Moderately significant probabilities, as $50 \% \leq \gamma \times 100<70 \%$.

$R$ : Residuals.

\section{Discussion}

The aim of this study was to describe and associate the levels of family resilience, parenting stress, and family poverty in order to outline a picture of how these variables are organized in the experiences of poor families in the city of Belém (PA), Brazil. The sample of this study is composed mainly of women, between mothers (91\%) and grandmothers (6\%), single (53\%), between 20 and 39 years old (69\%), and who finished High School (50\%). This characteristic may, in part, justify the high levels of stress found in the investigated population, since there is a consensus in the literature that there is a greater vulnerability to women who are assigned with caregiving roles in poor families (Oliveira, 2018). The overload of responsibilities experienced by these women is evident, since they carry out activities of different natures, characterized by double shifts, work and family life, which causes problems to their breadwinning role and the preservation of an effective participation in their children's lives and the family environment (Maia, Júnior, Souza, \& Araújo, 2016).

This reality can also be seen from the type of activities performed by mothers who have some kind of occupation, in addition to those who are stay-at-home mothers, since most of them reveal that they perform some kind of informal work $(66.4 \%$,), evidencing a precariousness in the access as well as maintaining an effective and formalized employment relationship, which can act as another stressor in the life of these mothers (Damaske, Brastter, \& Frech, 2016). 
In relation to the main variables of this study, resilience, stress and poverty, the results showed that none of the families were classified as highly resilient, which may indicate their vulnerability profile (Peixoto \& Martins, 2012). In addition, on the one hand, associations have been demonstrated between low resilience, high parenting stress and high poverty levels; and, on the other hand, associations between moderate resilience, low stress and low poverty levels.

The fact that none of the investigated mothers was considered to be members of highly resilient families suggests that the influence of the mutual relationship between stress and poverty experienced by these caregivers has produced effects on their responses to adversity. Thus, it is inferred that the exposure to these risk factors may limit the healthy development of skills and potentials that generate psychological growth and, therefore, the development of resilience, at individual and family levels (Shelleby, 2018).

This profile of the participants also suggests a state of "balance", and it can be understood that the degree of intensity of the regulatory processes that involve family resilience, at least with regard to the elements investigated by the instrument, is enough only to deal with the problems of everyday life. This suggests that the processes involved in family resilience, such as flexibility, coherence, and social support, do not decisively overcome the risk factors that make up the experiences of these families (Yunes \& Szymanski, 2007).

The association between low resilience, high parenting stress and high poverty allows the elaboration of some reflections and explanatory hypotheses about the systemic relationships established between the capacities and resources of families and the community (Patterson, 2002). It is evident that the increase in the levels of parenting stress and poverty can decrease the probability of parents to develop higher levels of functionality. It is understood that the parents' ability to face the adversities generated by poverty is limited by the scarcity of resources available in the community. This makes a lot of sense when dealing with poor families.

Additionally, the socially constructed beliefs about poverty, seen as unworthy and inferior, despite not being able to determine it, can influence the way individuals understand, feel and act in the face of the reality they experience (Cidade, Junior, \& Ximenes, 2017). In this sense, it is assumed that families who live in situations that facilitate the creation of feelings of hopelessness and helplessness may experience difficulties in coping and in the ability to reduce the impact of stressful situations.

Families classified as having moderate resilience had significant associations with low stress and lower poverty. It is observed that, although this group was classified as less poor, all families in this study comprise a group of poverty and were registered in the Cadúnico system when they participated in the research. This family profile allows researchers to say that such families live on the presence of significant risks for their own development (Patterson, 2002).

Despite being poor families, they presented a highly significant probability (100\%) of association between moderate resilience and low stress levels. This reveals the capabilities of these families to deal with adversity and the development of good emotional and relational regulations among their members. This level of family resilience may be the result of the action of protection mechanisms developed in the trajectory of family development, as well as the construction of new resources to deal with adversities. These resources are related to family members, the family unit, and their development contexts, as well as the stage of the life cycle (Henry et al., 2018). Therefore, the presence of assistance and more supportive relationships between the members and between the family, while contexts can be a crucial element for adjustment and adaptation (Maitoza, 2019; Patterson, 2002).

McCubbin and Patterson (1983) consider that a good adaptation occurs when there is a sense of coherence in the family despite the challenges that are established. For this, they emphasize that family health is related to the balance between the capacities and needs of the family system and their challenges. Therefore, the interactional and procedural characteristics in the development of resilience and the need not to understand it in terms of family dynamics, but of the possibilities and exchanges made with the 
development contexts (Patterson, 2002), are highlighted. In general, poverty is revealed as a serious adverse phenomenon that overloads the family's regulatory capacity and makes it difficult to establish new points of balance and good functioning of the family. Nevertheless, resilience is a complex phenomenon, marked by multiple and complex factors that can cushion the effects of poverty, such as the available support network. The support network has been shown to be associated with interactional quality among family members and with contexts that promote health opportunities and reduce or eliminate deprivations associated with poverty (MacPhee, Lunkenheimer, \& Riggs 2015).

\section{Conclusion}

The main contribution of this study is the possibility of understanding family organization and dynamics based on three variables, resilience, stress, and poverty, which are important in the development of human beings, whether adults or children. For that, the researchers used instruments to try to access different levels of family functionality, starting from parenting stress (which assesses the interactional quality in the caregiverchild subsystem), family resilience (which tries to reach the systemic aspects of family functionalities, from the intra-family interaction to the social support from the community) and poverty (as a multidimensional phenomenon that involves aspects strongly associated with development).

It was possible to visualize, in this study, how much the conditions of poverty affect, in different ways, family members and their functionalities. This relationship is demonstrated, for example, in groups with higher levels of parenting stress being associated with greater poverty levels. It was also demonstrated the relationship between poverty and the decrease in the possibility for families to build organizations and functionalities that promote the resilience process.

It is worth noting that poverty, as a significant risk for development, is not just an indicator, or an isolated event. It is a situation that alters and influences different areas of people's lives, preventing the freedom of individuals from reaching their full potential and responding to their developmental needs.

It is also important to highlight the sample characterization of this study, since the participating families are mainly headed by urban women living in the northern part of the country, with low professional qualifications and who have demonstrated that they are not part of the formal job market. These characteristics point to the existence of vulnerability factors for this group, which usually have little or no formal or informal social support.

It is observed that sociodemographic stressors, such as socioeconomic disadvantages, affect parental functioning, being associated with future child behavior problems, which impair self-regulation, at the individual level, and co-regulation of dyads. These processes mutually influence the development of the family system, and work together with other family processes that amplify or weaken its abrasive power. These results are in line with the family stress model, empirically supported by a broad body of research.

The limitations of this study are mainly related to its quantitative and cross-sectional design, which brought an overview of variables that influence human development, but it did not present a microscopic analysis of family processes or how they occur over time. One can also consider the fact that the resilience instrument has not been validated for the Brazilian population. This factor may have affected, albeit minimally, the participants' sensitivity to scales or items, which might not have been able to take their reality into account.

Still regarding the limitations of this study, the controversy over the use of scales to assess a phenomenon as procedural as resilience is highlighted. The display of averages and generalist results can also rule out one of the aspects that contributed to the emergence of resilience as a research phenomenon: individual variability. These discussions reveal the theoretical and methodological complexity of this concept, which deserves to be further studied for the creation of new forms of investigation. 
As demonstrated in this study, parenting stress, family resilience and poverty levels are mutually related and, therefore, are phenomena that require constant updating and methodological refinement, in order to reach their dynamics. Regarding family resilience, it is recommended for future studies to develop translations and validations of instruments that assess family resilience in the Brazilian context, since no family resilience instruments adapted to the Brazilian reality have been found.

It is also suggested that studies try to reach, through qualitative measures, the aspects that affect the intrafamily dynamics of Brazilian families, whether through interference in routine, family chaos, social support, etc. This will allow researchers to map out ways to facilitate the development of interventions and proposals that promote mental health and growth, as well as the understanding/changing of the individual, family, community, and social reality.

\section{Contributors}

I. C. P. SILVA, K. C. CUNHA, F. A. R. PONTES, and S. S. C. SILVA contributed to the data conception, design, analysis and interpretation; writing the manuscript, critical review of the content and approval of the final version to be published. E. M. L. S. RAMOS contributed to the data conception, design, analysis and interpretation.

\section{References}

Abidin, R. R. (1990). Parenting Stress Index test manual (3rd ed.). Charlottesville: Pediatric Psychology Press.

Abidin, R. R., Austin, W. G., \& Flens, J. R. (2013). The forensic uses and limitations of the Parenting Stress Index. In R. A. Archer \& E. M. A. Wheeler (Eds.), Forensic uses of clinical assessment instruments (pp.346-371). New York: Routledge.

Anjos, E. M., \& Astorga, C. M. (2016). A personalidade resiliente: uma conceptualização teórica. International Journal of Developmental and Educational Psychology, 2(1), 151-156. https://doi.org/10.17060/ijodaep.2016.n1.v2.297

Barros, R. P., Carvalho, M., \& Franco, S. (2006). Pobreza multidimensional no Brasil. Brasília: IPEA.

Bem, L. D., \& Wagner, A. (2006). Reflexões sobre a construção da parentalidade e o uso de estratégias educativas em famílias de baixo nível socioeconômico. Psicologia em Estudo, 11(1). 63-71. https://doi.org/10.1590/s1413-7372 2006000100008

Bronfenbrenner, U., \& Morris, P. A. (2006). The bioecological model of human development. In R. M. Lerner (Ed.), Handbook of child psychology, sixth edition: theoretical models of human development (pp.793-828). Hoboken: Wiley.

Bussab, W. O., \& Morettin, P. A. (2013). Estatística básica (8a ed.). São Paulo: Editora Saraiva.

Cidade, E. C., Junior, J. F. M., \& Ximenes, V. M. (2017). Implicações psicológicas da pobreza na vida do povo latino-americano. Psicologia Argumento, 30(68). https://doi.org/10.7213/psicol.argum.5886

Conger, R. D., \& Conger, K. J. (2002). Resilience in midwestern families: selected findings from the first decade of a prospective, longitudinal study. Journal of Marriage and Family, 6(4), 361-373. https://doi.org/10.1111/j.1741-37 37.2002.00361.x

Damaske, S., Bratter, J. L., \& Frech, A. (2016). Single mother families and employment, race, and poverty in changing economic times. Social Science Research, 62, 120-133. https://doi.org/10.1016/j.ssresearch.2016.08.008

Dell'Aglio, D. D., Koller, S. H., \& Yunes, M. A. M. (2011). Resiliência e psicologia positiva: interfaces do risco à proteção. São Pulo: Casa do Psicólogo.

Fávero, L., Belfiore, P., Silva, F., Chan, B. (2009) Análise dos dados: modelagem multivariada para tomada de decisões. Rio de Janeiro: Elsevier.

Henry, C. S., Hubbard, R. L., Struckmeyer, K. M., \& Spencer, T. A. (2018). Family resilience and caregiving. In W. A. Bailey \& A. W. Harrist (Eds.), Family caregiving (pp.1-26). Cham: Springer.

Hughes, S. O., Power, T. G., Liu, Y., Sharp, C., \& Nicklas, T. A. (2015). Parent emotional distress and feeding styles in low-income families: the role of parent depression and parenting stress. Appetite, 92(1), 337-342. https://doi. org/10.1016/j.appet.2015.06.002

Instituto Brasileiro de Geografia e Estatística. (2019). SIS-Síntese de indicadores sociais: uma análise das condições de vida da população brasileira: 2019. Rio de Janeiro: Autor. 
Lima, M. B. S., Cardoso, V. S., \& Silva, S. S. C. (2016). Parental stress and social support of caregivers of children with cerebral palsy. Paidéia, 26(64), 207-214. https://doi.org/10.1590/1982-43272664201608

MacPhee, D., Lunkenheimer, E., \& Riggs, N. (2015). Resilience as regulation of developmental and family processes. Family Relations, 64(1), 153-175. https://doi.org/10.1111/fare.12100

Maia, K., Júnior, A. D., Souza, S. D. C. I., \& de Araújo, F. B. (2016). O papel das mulheres pobres brasileiras na estrutura familiar monoparental feminina: uma análise do ano 2012. Revista Econômica, 17(2). https://doi.org/10.22409/ economica.17i2.p221

Main, G., \& Bradshaw, J. (2016). Child poverty in the UK: measures, prevalence and intra-household sharing. Critical Social Policy, 36(1), 38-61. https://doi.org/10.1177/0261018315602627

Maitoza, R. (2019) Family challenges created by unemployment. Journal of Family Social Work, 22(2), 187-205. https:// doi.org/10.1080/10522158.2018.1558430

McCubbin, M., \& McCubbin, H. (1993). Families coping with ilness: the resiliency model family stresse, adjustment, and adaptation. In C. Danielson, B. Hamel-Bissell, \& P. Winstead-Fry (Eds.), Families, health \& ilness: perspectives on coping and intervention (pp.21-63). Saint Louis: Mosby-Year Book.

McCubbin, H. I., \& Patterson, J. M. (1983). The family stress process. Marriage and Family Review, 6(1-2), 7-37. https:// doi.org/10.1300/j002v06n01_02

Nascimento, A. C, \& Curado, F. (2017). Programa de Atenção Integral à Família (PAIF): perfil das famílias cadastradas e fatores de vulnerabilidade. Revista Desafios, 4(3), 16-24. https://doi.org/10.20873/uft.2359-3652.2017v4n3p16

Oliveira, N. N. (2018). Pobreza das mulheres chefes de família da Região Nordeste do Brasil: uma análise multidimensional (Tese de doutorado não-publicada). Universidade Estadual do Oeste do Paraná.

Oliveira, K. S., Nakano, T. C., \& Silva, G. M. (2019). Children's resilience markers: criterionbased validity evidences. Estudos de Psicologia (Campinas), 36, e180142. https://doi.org/10.1590/1982-0275201936e180142

Patterson, J. M. (2002). Integrating family resilience and family stress theory. Journal of Marriage and Family, 64(2), $349-360$. https://doi.org/10.1111/j.1741-3737.2002.00349.x

Peixoto, M. J., \& Martins, T. (2012). Adaptação do perfil de resiliência familiar à população portuguesa. Psicologia, Saúde e Doenças, 13(2), 372-388.

Pereira, L. M., Viera, C. S., Toso, B. G. O, Carvalho, A. R. S, \& Bugs, B. (2016). Validação da escala Índice de Estresse Parental para o português do Brasil. Acta Paulista de Enfermagem, 29(6), 671-677. https://doi.org/10.1590/1982-01 94201600094

Reitman, D., Currier, R. O., \& Stickle, T. R. (2002). A critical evaluation of the Parenting Stress Index-Short Form (PSI-SF) in a head start population. Journal of Clinical Child and Adolescent Psychology, 31(3), 384-392. https://doi.org/10.1207/ s15374424jccp3103_10

Rozemberg, L., Avanci, J., Schenker, M., \& Pires, T. (2014). Resiliência, gênero e família na adolescência. Ciência e Saúde Coletiva, 19(3), 673-684. https://doi.org/10.1590/1413-81232014193.21902013

Santos, T. M., Silva, S. S. C, \& Koller, S. H. (2017). Percepção de mães beneficiárias ribeirinhas da Amazônia sobre o Programa Bolsa Família. Psicologia: Teoria e Pesquisa, 33(1). https://doi.org/10.1590/0102.3772e3341

Sen, A. (2018). Desenvolvimento como liberdade. São Paulo: Companhia das Letras.

Shelleby, E. C. (2018). Economic stress in fragile families: pathways to parent and child maladjustment. Journal of Child and Family Studies, 27(12), 3877-3886. https://doi.org/10.1007/s10826-018-1232-z

Silva, Í. C. P., Cunha, K. C, Ramos, E. M. L. S., Pontes, F. A. R., \& Silva, S. S. C. (2019). Estresse parental em famílias pobres. Psicologia em Estudo, 24. http://dx.doi.org/10.4025/1807-0329e40285

Sousa, V. F. S., \& Araújo, T. C. C. (2015). Estresse ocupacional e resiliência entre profissionais de saúde. Psicologia: Ciência e Profissão, 35(3), 900-915. https://doi.org/10.1590/1982-370300452014

Steele, H., Bate, J., Steele, M., Dube, S. R., Danskin, K., Knafo, H., ... Murphy, A. (2016). Adverse childhood experiences, poverty, and parenting stress. Canadian Journal of Behavioura/ Science, 48(1), 32. https://doi.org/10.1037/cbs0000034

Walsh, F. (2015). Strengthening family resilience. New York: Guilford Publications.

Yunes, M. A. M., \& Szymanski, H. (2007). O estudo de uma família "que supera as adversidades da pobreza": caso de resiliência familiar? Psicodebate, 7, 119-140. https://doi.org/10.18682/pd.v7i0.431

Received: September, 27, 2019

Final version: January 23, 2020

12

Approved: April 27, 2020 